\title{
Finding memory: Interview with Daniel L. Schacter*
}

Encontrando la memoria: Entrevista con Daniel L. Schacter

Recibido: agosto 3 de 2013 | Revisado: noviembre 10 de 2013 | Aceptado: diciembre 1 de 2013

\author{
CÉSAR ACEvedo-TrianA ** \\ Pontificia Universidad Javeriana, Colombia \\ FERNANDO CARDENAS P. *** \\ Universidad de los Andes, Colombia \\ FELIPE DE BRIGARD **** \\ Duke University, United States
}

doi:10.11144/Javeriana.UPSY12-5.fmid

Para citar este artículo: Acevedo-Triana, C., Cardenas, F. P., \& De Brigard, F. (2013). Finding memory: Interview with Daniel L. Schacter. Universitas Psychologica, 12(5), 1605-1610. doi:10.11144/Javeriana. UPSY12-5.fmid

We thank Dr. Schacter for his generosity in agreeing to do this interview.

** School of Psychology, Pontificia Universidad Javeriana, Bogotá, Colombia..E-mail: cesar.acevedo@ javeriana.edu.co. ResearcherID: E-1472-2011

*** Psychology Department, School of Social Science. Universidad de los Andes, Bogotá, Colombia. Email: lucarden@uniandes.edu.co

***** Assistant professor at Duke University in the Department of Philosophy, the Center for Cognitive Neuroscience, and the Duke Institute for Brain Sciences. E-mail: felipe.debrigard@duke.edu

\begin{abstract}
A B S T R A C T
The present interview offers an annotated dialogue with Dr. Daniel L. Schacter, in which we had the chance to learn about his findings, his current studies, in their implications for memory and cognition. Dr. Schacter is currently William R. Kenan, Jr. Professor of Psychology at Harvard University. With more than 40 years of professional experience in research on cognition, Dr. Schacter has published over 400 articles, many in top scientific journals, and some have been cited thousands of times. For his multiple theoretical and empirical contributions to the field of psychology, Dr. Schacter recently received the American Psychological Association's Award for Distinguished Scientific Contributions.

Keywords author

Memory, Daniel L. Schacter, Cognition, Harvard.

\section{RES U M E N}

En esta entrevista se presenta un diálogo con comentarios con el Dr. Daniel L. Schacter, en el cual tratamos de tener la oportunidad de aprender sobre sus hallazgos, sus estudios actuales y sus implicaciones para la memoria y la cognición. El Dr. Schacter es actualmente profesor William R. Kenan Jr. de psicología en la Universidad de Harvard. Con más de 40 años de experiencia profesional en investigación sobre cognición, el Dr. Schacter ha publicado cerca de 400 artículos, muchos en revistas de alto impacto y algunos han llegado a recibir más de mil citas. Por sus múltiples contribuciones teóricas y empíricas en el campo de la psicología, recibió recientemente el premio por contribuciones científicas distinguidas de la American Psychological Association.

Palabras clave

Memoria, Daniel L. Schacter, Cognición, Harvard.
\end{abstract}


Dr. Daniel L. Schacter received the 2012 American Psychological Association Award for Distinguished Scientific Contributions, honoring psychologists who have made outstanding theoretical or empirical contributions to the field of psychology (American Psychological Association, 2012a).

His work largely focuses on the cognitive psychology and neuroscience of memory. Dr. Schacter has published over 400 papers, hundreds of which have appeared in some of the best scientific journals in the world. According to Google Scholar, his articles have been cited over 50,000 times, with some of them having been cited over 1,000 times each. A world-known leading authority in the topic of memory, Dr. Schacter has made important contributions to our understanding of the psychological and neural mechanisms underlying memory formation, retention and retrieval both for healthy individuals as well as for patients with a number of neurological pathologies.

Dr. Schacter received his BA from the University of North Carolina, Chapel Hill, in 1974 and a $\mathrm{PhD}$ in psychology from the University of Toronto in 1981, working under the supervision of Dr. Endel Tulving. In 1981 he founded the Memory Disorders Unit at the University of Toronto along with Dr. Tulving and Dr. Morris Moscovitch. Dr. Schacter remained at the University of Toronto as research associate and assistant professor until 1987, when he moved to the University of Arizona. In 1991 he became Professor of Psychology at Harvard University where he has remained since. In addition to his scientific articles, Dr. Schacter has written several award-winning books, including Searching for Memory in 1996, and The Seven Sins of Memory in 2001. Dr. Schacter is a member of the editorial board of a number of scientific journals, and has been an associate editor of Perspectives in Psychological Science and the Annual Review of Psychology. In addition to this recent award, he has received numerous prizes throughout his career, including the American Psychological Association Award for Distinguished Scientific Early Career Contributions to Psychology (1990), the Troland Research Award (1991) and the Award for Scientific Reviewing (2005) from the National Academy of Sciences (American Psychologi- cal Association, 2012a; 2012b), and Warren Medal (2009) from Society of Experimental Psychologists. $\mathrm{He}$ is also a fellow of the Society of Experimental Psychologists as well as the American Academy of Arts and Sciences.

The current interview has two parts. In the first part we hope to offer a general overview of some key results of Dr. Schacter's experimental work. In the second part, we will explore some of his ideas as to how these results might help to transform our concept of memory as well as their potential implications from a practical standpoint. As mentioned before, this is an annotated interview, so a number of answers are appended by short comments and relevant references.

\section{First Part}

Question. From your many contributions to the science of memory could you think of some that stand out as more representative, or perhaps more interesting to you?

Dr. Schacter: In the early part of my research career, during the 1980s, our work on priming was of great interest to me. Priming refers to a nonconscious influence of past experience on current performance and behavior. We explored priming in both amnesic patients and healthy individuals, and helped to characterize it as a type of implicit memory that can function independently of explicit or conscious memory. During the same time, we were able to show that preserved priming and implicit memory in amnesic patients could be used a basis for teaching amnesic individuals new knowledge and skills that they could use in everyday life.

Later, in the 1990s, I became interested in memory distortion and started to examine how memory errors are related to brain function. Some of our studies using neuroimaging to distinguish between true and false memories on the basis of brain activity were especially interesting to me. The idea that memory errors can be classified into seven basic categories, or "sins", was also a major focus during the 1990s and early 2000s. 
More recently, I have been especially interested in how memory is used to construct simulations of possible future experiences, and what that tells us about the nature and function of memory.

Comment: In relation to the first part of answer, a relevant paper is (Tulving \& Schacter, 1990). In this work the authors offer evidence for priming and discuss its implications. One such implication is that perceptual priming appears to involve processing in perceptual brain areas that are relatively independent of those engaged during episodic memory (Schacter, Delaney, \& Merikle, 1990; Tulving $\&$ Schacter, 1990). Additionally, unlike declarative memory, priming seems to be independent of consciousness, is relatively impervious to certain amnestic drugs, is preserved in patients with memory deficits due to medial temporal lobe damage (Schacter, Cooper, Tharan, \& Rubens, 1991) and exhibits a parallel distributed system of representational form (Ochsner, Chiu, \& Schacter, 1994; Schacter, Chin, \& Ochsner, 1993).

In regards to the second part of the answer, stands out the publication of his book "The Seven Sins of Memory" (Schacter, 1999; Schacter, 2002), where Schacter offers an account of the relationship between mistakes, failures and distortions of memory according to seven alterations or "sins": three sins of omission-transience, absentmindedness, and blocking-related to the inability to consolidate a memory, and four sins of commission-- misattribution, suggestibility, bias and persistence--related to contamination or intrusion of information in memory (Schacter, 2002).

The last part of the answer, linking memory and future simulations, can be found in a number of recent publications (Addis, Pan, Vu, Laiser, \& Schacter, 2009; Addis, Wong, \& Schacter, 2007; Gaesser, Spreng, Mclelland, Addis, \& Schacter, 2013; Schacter, Gaesser, \& Addis, 2013; Schacter et al., 2012; Schacter, Addis, \& Buckner, 2007; Schacter \& Addis, 2007, 2009; van Mulukom, Schacter, Corballis, \& Addis, 2013). More recently, Dr. Schacter has expanded some of these ideas to simulations involving counterfactual thinking (De Brigard, Addis, Ford, Schacter, \& Giovanello, 2013; De Brigard, Szpunar, \& Schacter, 2013).
Question. Recently, you and your colleagues have shown that remembering one's personal past and imagining a possible personal future depend on a common Default Brain Network. However, thinking about the past and thinking about the future appear to us as two distinguishable cognitive processes. How do you think that the same neural network manages to differentiate these two processes?

Dr. Schacter: That is an important question. In addition to showing that remembering the past and imaging the future depend on a shared network, we have consistently found that some brain regions show different activity during these two processes, usually taking the form of greater activity when people imagine the future than remember the past. So it will be important to understand in more detail what those brain regions are doing. There is a long line of research in cognitive psychology indicating that remembered events are characterized by greater access to perceptual details than are imagined events, and some of our work is consistent with that line of work.

Comment: The Default Brain Network refers to a network of brain structures shown to be consistently active while subjects are not directly involved in online tasks. Recent reviews of studies showing default brain activation, along with their theoretical implications, include (Buckner, Andrews-Hanna, \& Schacter, 2008; Schacter, 2012; Szpunar, Addis, McLelland, \& Schacter, 2013). Critical brain regions of the default network include the medial temporal lobe, the medial prefrontal cortex, and the posterior cingulate cortex and precuneus (Buckner et al., 2008).

Question. False and distorted memories are a common occurrence. Do you think that these experiences might somehow affect our self-awareness? If so, how?

Dr. Schacter: Yes, I think that false and distorted memories can affect our self-awareness. For example, sometimes we falsely remember having experienced events that we only imagined. This kind 
of process may have been at work in some cases in the controversy concerning recovered memories of childhood sexual abuse that occurred during the 1990s, where some people came to falsely believe that they had been abused as children when in fact they only imagined that such events might have occurred. These kinds of memory distortions can have a profound effect on what we think about ourselves. Memory can also be shaped by our views of ourselves and in fact memory distortions sometimes occur as a consequence of trying to enhance our positive feelings about ourselves. A good example of this is one of the seven sins of memory, which I call bias, where what we currently know, believe, and feel about ourselves can result in distorted recollections of what happened to us in the past.

Comment: Recent developments in cognitive psychology and neuroscience of memory have shown to have profound implications for the law. The evidence that memory is reconstructive, liable and prone to distortion already has affected the way witness testimony is treated in court. The possibility of using neuroimaging to distinguish true from false memories is yet another way in which memory and law might interact. A recent article published in Nature Neuroscience discusses some of this issues (Schacter \& Loftus, 2013).

Question. Is there a relationship between the production of new neurons in the hippocampus and memory enhancing and/or strengthening?

Dr. Schacter: There is some evidence from neuroscience research consistent with that idea, but my lab has not been involved in any such work.

Comment: The relationship between memory and neurogenesis is an emerging field of study. Developments in this field of study can be found in the work of Frankland, Köhler, \& Josselyn (2013); Frankland, Teixeira, \& Wang (2007), and computational theorists Chambers, Potenza, Hoffman, \& Miranker (2004); Noguès, Corsini, Marighetto, $\&$ Abrous, (2012).

\section{Second Part}

Question. Research on memory has occupied much of your academic career. Can you think of ways in which your concept of 'memory' has changed throughout that time?

Dr. Schacter: There has been a general trend to think of memory less as a single entity and more as a set of multiple, interacting systems, and that has been true of my own thinking. I have also focused increasingly on the functions that various kinds of memory serve, and the ways in which memory affects our ability to perform tasks that we don't ordinarily think of as involving memory - such as imagining the future or solving problems.

Question. Stored memories do not remain unchanged from encoding to retrieval. They change over time. What are the mechanisms responsible for those changes? Is there a point in which too much transformation to our memories might become detrimental to the subject?

Dr. Schacter: There are probably several mechanisms that contribute to changes in memory over time. We know that the act of retrieving a memory affects the subsequent state of that memory and related information - depending on a variety of circumstances, retrieving a past experience can strengthen or change that experience and possibly weaken related experiences that aren't retrieved. There has been a lot of interest recently in the possibility that such changes may be the result of a phenomenon known as "reconsolidation". Consolidation refers to the fact that it takes some time for memories to become established in the brain. Reconsolidation refers to the finding that when a previously consolidated memory is reactivated or retrieved, it temporarily enters an unstable state where it can be altered or possibly eliminated. The memory must be consolidated all over again (hence the term "reconsolidation"), but the reconsolidated 
memory might differ from the original one - if, for example, new information is incorporated into the memory during the reconsolidation process. So far, most of the evidence on reconsolidation has come from studies of rats and mice, but there is some evidence from humans now indicating a possible role for reconsolidation in memory changes over time.

Question. Your work, as well as results coming from other labs, has shown that the Brain Default Network is implicated in a number of seemingly unrelated cognitive tasks, such as mentalizing, future thinking, episodic recollection and moral decision making, to name a few. Do you think we can keep these psychological categories and still make sense of such results, or do you think that the discovery of such commonalities in the brain might force us to rethink the way in which we understand these basic psychological processes?

Dr. Schacter: It is too early to say for sure, but my guess is that in the long run, we will have to rethink our conceptualizations of some of these basic psychological processes. This may turn out to be a case where seeing unexpected commonalities among seemingly distinct psychological processes causes us to re-conceptualize the basic nature of those processes.

Question. Recent studies have reported that some drugs appear to enhance memory in patients with Alzheimer's disease (Benedict et al., 2007; Craft et al., 2003; Reger et al., 2004; Schwartz et al., 1996). Does this mean that medical drugs can enhance cognitive function where there has been loss of neuronal tissue? And, it so, do you think that the same effect might be possible for other pathologies?

Dr. Schacter: Unfortunately a number of recent drug trials focused on patients with Alzheimer's disease have not yielded positive results, so I think that we are going to need a lot more research before we are in a good position to answer this question.

\section{References}

Addis, D. R., Pan, L., Vu, M.-A., Laiser, N., \& Schacter, D. L. (2009). Constructive episodic simulation of the future and the past: distinct subsystems of a core brain network mediate imagining and remembering. Neuropsychologia, 47(11), 2222-2238. doi:10.1016/j.neuropsychologia.2008.10.026

Addis, D. R., Wong, A. T., \& Schacter, D. L. (2007). Remembering the past and imagining the future: common and distinct neural substrates during event construction and elaboration. Neuropsychologia, 45(7), 1363-1377. doi:10.1016/j.neuropsychologia.2006.10.016

American Psychological Association (2012a). Daniel L. Schacter: Award for Distinguished Scientific Contributions. American Psychologist, 67(8), 601-603. doi:10.1037/a0029701

American Psychological Association (2012b). Awards for Distinguished Scientific Contributions. American Psychologist, 67(8), 586-587. doi:10.1037/h0094706

Benedict, C., Hallschmid, M., Schultes, B., Born, J. \& Kern, W. (2007). Intranasal Insulin to Improve Memory Function in Humans. Neuroendocrinology, 86, 136-142. doi: 10.1159/000106378

Buckner, R. L., Andrews-Hanna, J. R., \& Schacter, D. L. (2008). The brain's default network: anatomy, function, and relevance to disease. Annals of the New York Academy of Sciences, 1124, 1-38. doi:10.1196/ annals.1440.011

Chambers, R. A., Potenza, M. N., Hoffman, R. E., \& Miranker, W. (2004). Simulated apoptosis/neurogenesis regulates learning and memory capabilities of adaptive neural networks. Neuropsychopharmacology, 29(4), 747-758.

De Brigard, F, Addis, D. R., Ford, J. H., Schacter, D. L., \& Giovanello, K. S. (2013). Remembering what could have happened: Neural correlates of episodic counterfactual thinking. Neuropsychologia, 51(12), 2401-2414.

De Brigard, Felipe, Szpunar, K. K., \& Schacter, D. L. (2013). Coming to grips with the past: effect of repeated simulation on the perceived plausibility of episodic counterfactual thoughts. 
Psychological Science, 24(7), 1329-1334. doi:10.1177/0956797612468163

Frankland, P. W., Köhler, S., \& Josselyn, S. a. (2013). Hippocampal neurogenesis and forgetting. Trends in neurosciences, 36(9), 497-503. doi:10.1016/j. tins.2013.05.002

Frankland, P. W., Teixeira, C. M., \& Wang, S.-H. (2007). Grading the gradient: Evidence for time-dependent memory reorganization in experimental animals. Debates in Neuroscience, 1(2-4), 67-78. doi:10.1007/ s11559-007-9004-8

Gaesser, B., Spreng, R. N., Mclelland, V. C., Addis, D. R., \& Schacter, D. L. (2013). Imagining the future: Evidence for a hippocampal contribution to constructive processing. Hippocampus, 23 (12), 1150-1161. Doi: 10.1002/hipo.22152

Noguès, X., Corsini, M. M., Marighetto, A., \& Abrous, D. N. (2012). Functions for adult neurogenesis in memory: An introduction to the neurocomputational approach and to its contribution. Behavioural Brain Research, 227(2), 418-425.

Ochsner, K. N., Chiu, C.Y. P., \& Schacter, D. L. (1994). Varieties of priming. Current Opinion in Neurobiology, 4(2), 189-194.

Schacter, D. L., Chin, C.Y. P., \& Ochsner, K. N. (1993). Implicit memory: A selective review. Annual Review of Neuroscience, 16, 159-182.

Schacter, D. L., Cooper, L. A., Tharan, M., \& Rubens, A. B. (1991). Preserved priming of novel objects in patients with memory disorders. Journal of Cognitive Neuroscience, 3(2), 117-130.

Schacter, D. L., Delaney, S. M., \& Merikle, E. P. (1990). Priming of Nonverbal Information and the Nature of Implicit Memory. In Psychology of Learning and Motivation - Advances in Research and Theory, Vol. 26. New York: Acamedic Press

Schacter, D. L., Gaesser, B., \& Addis, D. R. (2013). Remembering the past and imagining the future in the elderly. Gerontology, 59(2), 143-151.
Schacter, D. L. (1999). The Seven Sins of Memory. American Psychologist, 54(3), 182-203.

Schacter, D. L., Addis, D., Hassabis, D., Martin, V., Spreng, R., \& Szpunar, K. (2012). The Future of Memory: Remembering, Imagining, and the Brain. Neuron, 76(4), 677-694.

Schacter, D. L. (2012). Adaptive Constructive Processes and the Future of Memory. American Psychologist, 67(8), 603-613. doi:10.1037/a0029869

Schacter, D. L., \& Addis, D. R. (2007). The ghosts of past and future. Nature, 445, 27.

Schacter, D. L., \& Addis, D. R. (2009). On the nature of medial temporal lobe contributions to the constructive simulation of future events. Philosophical transactions of the Royal Society of London. Series B, Biological sciences, 364(1521), 1245-1253. doi:10.1098/rstb.2008.0308

Schacter, D. L., Addis, D. R., \& Buckner, R. L. (2007). Remembering the past to imagine the future: the prospective brain. Nature Reviews Neuroscience, 8(9), 657-661. doi:10.1038/nrn2213

Schacter, D. L. (2002). The Seven Sins of Memory: How the Mind Forgets and Remembers (p. 288). Houghton Mifflin Harcourt.

Schacter, D. L., \& Loftus, E. (2013). Memory and Law: what can cognitive neuroscience contribute? Nature Neuroscience, 16(2), 119-123. doi:10.1038/nn.3294

Szpunar, K. K., Addis, D. R., McLelland, V. C., \& Schacter, D. L. (2013). Memories of the future: New insights into the adaptive value of episodic memory. Frontiers in Behavioral Neuroscience 7, 47. Doi: 10.3389/fnbeh.2013.00047

Tulving, E., \& Schacter, D. L. (1990). Priming and human memory systems. Science, 247(4940), 301-306.

Van Mulukom, V., Schacter, D. L., Corballis, M. C., $\&$ Addis, D. R. (2013). Re-Imagining the Future: Repetition Decreases Hippocampal Involvement in Future Simulation. PLoS ONE, 8(7). 